$\mathrm{Hal}: 47-52$

\title{
KEPEMIMPINAN KEPALA SEKOLAH DALAM MENINGKATKAN MOTIVASI MENGAJAR GURU DI SMP N 2 SIGAMBAL
}

\author{
Risma Delima Harahap \\ Program Studi Pendidikan Biologi, STKIP Labuhan Batu, \\ Email: rismadelimaharahap@gmail.com
}

Diterima April 2018 dan Disetujui Juni 2018

\begin{abstract}
ABSTRAK
Penelitian ini bertujuan untuk mengetahui kepemimpinan kepala sekolah di SMP N 2 Sigambal kemudian upaya kepala sekolah dalam meningkatkan motivasi mengajar guru, dan mengungkapkan kepemimpinan kepala sekolah dan motivasi mengajar guru di SMP N 2 Sigambal. Adapun populasi dalam penelitian ini adalah kepala sekolah dan guru yang berjumlah 20 orang. Hasil wawancara di lapangan dengan kepala sekolah dan sebagian guru yang ada di SMP N 2 Sigambal, kesimpulannya bahwa kepemimipinan kepala sekolah dalam meningkatkan motivasi guru yang ada disekolah tersebut yang pertama dilaksanakannya melihat manajemen operasional sekolah, dengan cara pelaksanaan kurikulum dan pengajaran kesiswaan, personalia guru, dan tenaga administrasi, sarana dan prasarana, keuangan, serta hubungan dengan orang tua murid dan kerabat murid, selalu cenderung dilakukan dengan menerapkan tipe demokratis. Dalam upaya meningkatkan motivasi mengajar guru dilakukan dengan langkah-langkah meningkatkan kesejahteraan guru, transparansi keuangan sekolah, selalu membuka dialog dengan guru sesering mungkin, memberikan penghargaan kepada guru yang berprestasi, serta terus menerus melengkapi sarana dan prasarana. Adanya pengaruh kepemimpinan kepala sekolah terhadap peningkatan motivasi mengajar guru dapat terjadi dengan baik dikarenakan adanya rasa kebersamaan diantaranya, rasa kekeluargaan, rasa memiliki, rasa tanggung jawab serta tumbuh keinginan untuk maju secara bersama.

Kata-kata Kunci : Kepemimpinan Kepala Sekolah, Peningkatan Motivasi Mengajar Guru.
\end{abstract}

\section{PENDAHULUAN}

Sebuah sekolah yang dipimpin oleh kepala sekolah haruslah mempunyai sikap ingin maju dan disiplin. Kepala sekolah berperan penting dalam menentukan arah dan tujuan mau diarahkan kemana sekolah yang ia pimpin. Baik buruknya sekolah itu adalah tanggung jawab dari kepala sekolah, maka dari itu kepala sekolah harus mampu dan menguasai manajerial yang handal untuk diterapkan disekolahnya agar dapat memajukan sekolah yang dipimpinnya. Kepala sekolah harus lah mengetahui manajemen operasional sekolah dan mampu membuat kebijakan yang tepat untuk sekolahnya, dan mampu mengambil keputusan yang sifatnya memperlancar dan meningkatkan kualitas penyelengraan pendidikan. Kepala sekolah sebagai pemimpin disekolahnya harus dapat memberikan rangsangan kepada guru serta personal pendidikan lainnya untuk mengusahakan peningkatan dan pengembangan pendidikan disekolahnya.

Prinsipnya proses kepemimpinan ialah pengaturan yang bijaksana. Maka apabila dikuasai dengan baik akan dapat menjadikan salah satu kunci sukses bagi kepala sekolah dalam memangku jabatannya sebagai pemimpin dan motivator yang mengarahkan para bawahannya terutama guru-guru agar tetap maksimal dalam menjalankan tugasnya sehari-hari. Salah satu tugas dalam kepemimpinan kepala sekolah yang sangat penting adalah untuk menyusun program belajar mengajar di sekolahnya dan menempatkan tugas masing-masing guru, dimana dalam hal ini guru sabagai pelaksana pendidikan di sekolah. Maka dari itu kepala sekolah harus benar-benar menjalin komunikasi yang aktif dan setiap saat harus melaksanakan evaluasi kerja terhadap tugas pengajaran yang sudah dilaksanakan guru. Supaya guru dapat menjalankan tugasnya secara baik dan benar, maka kepala sekolah harus mengetahui dan memberikan motivasi kepada bawahannya atau guru-guru yang ada disekolahnya. Setelah itu dalam program penetapan tujuan, sekolah tidak dibenarkan memaksakan tujuan yang terlalu tinggi atau kurang realistis kepada guru. Dalam hal ini J. Sterling Livingston dengan tetap mengatakan bahwa : " Bawahan tidak akan termotivasi untuk mencapai level produktivitas yang tinggi apabila mereka merasa harapan itu realistis, tidak dapat dicapai. Apabila mereka terus didorong untuk mencapainya, maka pada akhirnya mereka akan berhenti mencoba dan lebih suka mencapai hasil yang lebih rendah dari pada yang sebenarnya dapat mereka capai. Kepala sekolah sebagai 
$\mathrm{Hal}: 47-52$

pemimpin di sekolah idealnya haruslah dekat dan komunikatif dengan semua guru menjalin persahabatan diantaranya, karena ia akan berhadapan langsung dengan semua guru di sekolah itu yang terdiri latarbelakang yang berbeda-beda pastinya. Sederhananya Kepala sekolah harus mempunyai kemampuan dalam meningkatkan mutu sekolah, sekolah yang berkualitas tidak terlepas dari propesionalitas seorang Kepala sekolah dalam menjalankan manajemen operasional. Untuk Staf atau kepegawaian Kepala sekolah sebagai seorang manajer harus dapat membangkitkan motivasi yang kuat bagi seluruh sumber daya yang ada, terutama bagi para guru yang ada disekolah yang dipimpinnya.

Dengan kata lain tugas kepemimpinan kepala sekolah secara umum ialah memberikan motivasi kepada guru agar menjalankan tugasnya sesuai fungsinya dan melengkapi diri dengan tugas pokok, sehingga dalam proses belajar mengajar terlaksana dengan baik tidak merugikan anak didik.

Berdasarkan studi pendahuluan dan observasi dilapangan bahwa di sekolah SMP N 2 Sigambal, sikap kepala sekolah masih jauh dari keakraban kepada guru-gurunya. Otoriter kepala sekolah masih saja terlihat, dan motivasi kerja masih tergolong rendah. Maka dari itu penulis mengangkat judul mengenai Kepemimpinan Kepala Sekolah Dalam Meningkatkan Motivasi Mengajar Guru Di SMP N 2 Sigambal

\section{METODE PENELITIAN \\ Mengenal Lokasi Penelitian}

Penelitian ini dilakasanakan di SMP N 2 Sigambal, di jalan HM. Said Kecamatan Rantau Selatan Kabupaten Labuhanbatu. SMP N 2 Sigambal ini merupakan salah satu tingkatan sekolah yang dikelola oleh Pemkab Labuhanbatu. Bangunan ini terdiri dari satu gedung yang terdiri dari 21 ruangan kelas. Sekolah ini, termasuk sekolah yang baik yang dari waktu ke waktu mengalami perkembangan atau kemajuan yang berarti, hal ini ditandai dengan semakin bertambahnya jumlah siswa yang masuk menjadi siswa di sekolah ini. Begitu pula pertambahan dan perkembangan sarana dan prasarana yang dimiliki sekolah ini semakin meningkat dari waktu ke waktu.

Adapun jumlah guru yang mengajar di SMP N 2 Sigambal ini jumlahnya 20 orang guru. Berpendidikan S1 sebanyak 18 orang dan berpendidikan D.III sebanyak dua (2) orang. Sebagian besar dari guru tersebut adalah berlatar belakang pendidikan guru atau bergelar S.Pd. Untuk mendukung tugas guru tersebut dibantu oleh tenaga administrasi sebanyak tiga (3) orang.

\section{Objek dan Subjek Penelitian}

Objek penelitian ini adalah mengenai kepemimpinan Kepala SMP N 2 Sigambal.

\section{Sumber Data}

Sumber data primer dalam penelitian ini adalah kepala sekolah SMP N 2 Sigambal. Sumber data sekunder dalam penelitian ini adalah guru-guru di SMP N 2 Sigambal, dokumen serta buku-buku atau literatur yang membahas masalah berkenaan dengan masalah yang diteliti.

\section{Instrumen Pengumpulan Data}

Observasi dan wawancara, yaitu melakukan serangkaian tanya jawab secara langsung dengan kepala sekolah dan guru-guru yang telah ditetapkan sebagai subjek penelitian.

\section{Teknik Analisa Data}

Analisa data yaitu cara mengorganisasikan dan mengurutkan data kedalam pola yang ada, kategori dan satuan uraian dasar sehingga dapat ditemukan tema dan dapat dirumuskan hipotesis kerja seperti yang disarankan oleh data.

\section{HASIL DAN PEMBAHASAN \\ Kepemimpinan Kepala Sekolah SMP N 2 Sigambal}

Sebelum dikemukakan lebih lanjut mengenai pelaksanaan kepemimpinan kepala sekolah SMP N 2 Sigambal, terlebih dahulu dikemukakan mengenai profil kepala sekolah tersebut. Kepala SMP N 2 Sigambal ini adalah Bapak Zunaidy S.Pd.,M.Pd, beliau lahir tahun 1970 di Sidimpuan. Pendidikan terakhirnya adalah alumni Jurusan Matematika Pasca Sarjana Universitas Negeri Medan, telah menikah dan memiliki tiga (3) orang anak. Beliau bertugas di sekolah ini sejak tahun 1995, mula-mula hanya sebagai guru biasa, namun setelah tahun 2000 beliau diangkat menjadi kepala sekolah. Pengalaman yang beliau gunakan untuk memimpin sekolah ini adalah pengalaman kependidikan yang beliau terima ketika menjadi mahasiswa di Fakultas Tarbiyah IAIN Sumatera Utara dan Pasca Sarjana Universitas Negeri Medan serta pengalaman menjadi guru selama beberapa tahun. Pelaksanaan kepemimpinan yang dianalisis melalui penelitian ini adalah pelaksanaan yang mengarahkan, mengatur, mengevaluasi dan mengawasi yang dilaksanakan kepala SMP N 2 Sigambal berkenaan dengan sisi operasional fungsi manajemen atau menejemen opresional sekolah. Oleh karena itu hal-hal yang diamati dalam penelitian ini adalah yang berkenaan dengan hal-hal berikut ini : 
Hal : 47 - 52

\section{Kurikulum dan Pengajaran}

Berdasarkan wawancara yang telah dilakukan penulis dengan kepala SMP N 2 Sigambal Bapak Zunaidy S.Pd.,M.Pd adalah Pertama sekali yang dilakukan kepala sekolah adalah menindaklanjuti dari penentuan kurikulum yang diberlakukan pemerintah agar dilaksanakan di sekolahnya sesuai dengan ketentuan pemerintah. Menindak lanjuti ini dilakukan dengan cara memberlakukan kurikulum tersebut untuk dipedomani dan dilaksanakan di sekolah yang dipimpin, terutama oleh guru dan dipergunakan dalam rangka menyusun program pengajaran. Program pengajaran disusun guru antara lain berdasarkan kurikulum yang telah ditetapkan. Program pengajaran yang disusun guru meliputi program semesteran dan tahunan serta adanya kegiatan minggu efektif dalam setiap semesternya.

\section{Kesiswaan}

perencanaan pembinaan siswa disusun oleh kepala sekolah melalui kegiatan kurikuler, kokurikuler dan ekstra kurikuler. Perencanaan pembinaan disusun berdasarkan kebutuhan siswa, kemampuan melaksana serta ketersediaan sarana dan prasarana. Adapun pembinaan terhadap siswa dilakukan melalui kegiatan belajar di kelas, kegiatan OSIS, Pramuka, kegiatan keagamaan dan sebagainya yang ada disekolah.

\section{a. Guru}

guru merupakan komponen yang sangat menentukan disekolah. Guru memegang tanggung jawab dalam pelaksanaan proses belajar-mengajar di dalam kelas. Maka dari itu guru perlu ditatar oleh kepala sekolah agar efektif dan efisien dalam melaksanakan tugasnya. Hasil dari pelaksanaan tugas guru tersebut ialah siswa dapat menguasai pelajaran sehingga memperoleh nilai hasil belajar yang tinggi, memiliki keterampilan serta mampu menunjukkan kepribadian yang mandiri dan handal.

\section{b. Tenaga Administrasi}

Tugas-tugas kesekretariatan dalam bentuk surat-menyurat, penyaiapan laporan dan pemeliharaan alat-alat sekolah di kelolah oleh tenaga administrasi sekolah.

\section{Tugas-tugas pokok tenaga admistrasi ini meliputi : \\ 1. Surat-menyurat \\ 2. Memberikan pelayanan kepala pimpinan sekolah, guru dan murid \\ 3. Membuat laporan}

\section{Sarana dan Prasarana}

Seluruh peralatan yang dibutuhkan untuk memperlancar atau melaksanakan kegiatan pengajaran di sekolah agar berjalan dengan lancar adalah sarana dan prasarana yang memadai. Sarana dan prasarana tersebut meliputi gedung, ruangan belajar, bangku, kursi, papan tulis dan sebagainya yang biasanya disebut dengan perangkat keras. Selain itu ada juga sarana dan prasarana yang berbentuk perangkat lunak, seperti kurikulum, silabus, peraturan dan disiplin sekolah dan sebagainya.

Kepala sekolah menyusun perencanaan pengadaan dan penggunaan sarana dan prasarana dengan baik. Perencanaan disusun berdasarkan kebutuhan pimpinan sekolah, guru-guru serta siswa serta seluruh komponan yang berkaitan dengan pelaksanaan dan pencapaian tujuan disekolah tersebut. Pelaksanaan atau penggunaan seluruh sarana dan prasarana diarahkan kepala sekolah agar terfokus pada renacana yang telah disusunnya sehingga pelaksanaannya sesuai dengan rencana dan memang benar-benar dibutuhkan oleh sekolah tersebut. Maka dari itu kepala sekolah terus memberikan pengarahan kepada petugas penggunaan sehingga dapat diketahuinya dengan tepat tentang pelaksanaan rencana pembinaan yang diberikan kepadanya untuk efektifitas dan efiseiensi penggunaan sarana dan prasarana tersebut.

\section{Keuangan}

Pemimpin atau kepala sekolah haruslah menyusun perencanaan penerimaan dan penggunaan keuangan sekolah dengan baik dalam kurun waktu tertentu contohnya, sebulan, satu semester, setahun dan sebagainya sesuai dengan kebutuhan dan penggunaannya. Perencanaan disusun oleh kepala sekolah berdasarkan kebutuhan pimpinan sekolah, guru, siswa serta seluruh komponan yang berkaitan dengan pelaksanaan dan pencapaian tujuan sekolah.

Penerimaan dan pengeluaran keuangan sekolah memerlukan biaya yang harus diketahui oleh kepala sekolah, karena itu kepala sekolah perlu menyediakan dana untuk hal tersebut. Pendaaan dilakukan mulai dari pengumpulan informasi kegiatan atau bahan - bahan sampai kegiatan membuat laporan petanda bahwa kegiatan telah sesuai dilaksanakan baik secara administratif dan secara real.

\section{Hubungan dengan orang tua murid}

Kepala sekolah bekerjasama dengan pengurus komite sekolah menyusun perencanaan program selama satu tahun. Perencanaan disusun berdasarkan kebutuhan pimpinan sekolah, guru serta siswa serta seluruh komponan yang berkaitan dengan pelaksanaan dan pencapaian tujuan sekolah. Pelaksanaan program komite sekolah diarahkan kepala sekolah agar terfokus pada rencana yang telah disusun sehingga pelaksanaannya sesuai dengan rencana dan 
$\mathrm{Hal}: 47-52$

memang benar-benar dibutuhkan oleh sekolah melalui komite sekolah itu hal yang telah dilakukan oleh kepala sekolah SMP N 2 Sigambal.

\section{Meningkatkan Kesejahteraan}

Usaha untuk terus meningkatkan kesejahteraan guru dilakukan kepala sekolah sesuai dengan kemampuan keungan sekolah, di mana sumber utama penerimaan sekolah adalah iuran komite sekolah yang diterima dari orang tua atau wali siswa di samping bantuan pemerintah yang terbatas dan bersifat priodik. Sumber-sumber pendapatan tersebut ternyata belum mampu memberikan tingkat kesejahteraan yang tinggi bagi guru.

\section{Transparansi Pengelolaan Keuangan}

Kepala sekolah terus mengupayakan agar dalam menentukan kebijakan keuangan pihak guru dilibatkan sehingga para guru mengetahui tentang pengelolaan keuangan di sekolah. Hal ini dilakukan dalam rangka menumbuhkan rasa memiliki, rasa kebersamaan dan rasa tanggung jawab di kalangan guru terhadap pelaksanaan proses belajar dan mengajar yang dilaksanakan di sekolah ini.

Di dalam diri guru juga akan tumbuh rasa tanggung jawab untuk melaksanakan dan memajukan kegiatan pendidikan yang ada di sekolah ini. Rasa tanggung jawab yang kuat itu akan menumbuhkan pula motivasi mengajar mereka karena mereka merasa bagian dari proses yang sedang berjalan. Rasa kebersamaan muncul karena adanya keterbukaan diantara sesamanya, dalam hal ini keterbukaan pengelolaan keuangan. Guru menjadi lebih aktif, giat dan ulet dalam melaksanakan tugasnya karena secara material mereka mendapatkan hasil yang didapatkan sekolah tempat mereka mengajarkan ilmunya.

\section{Melengkapi Sarana dan Fasilitas}

Kepala sekolah SMP N 2 Sigambal terus menerus berupaya meningkatkan sarana dan prasarana yang dapat membantu memperlancar pelaksanaan tugas mengajar, yaitu dengan berusaha melengkapi bukubuku paket, alat-alat peraga, media dan sumber belajar serta meja dan bangku guru sehingga guru dapat melaksanakan tugasnya dengan baik.

\section{Motivasi Mengajar Guru SMP N 2 Sigambal}

Motivasi mengajar guru SMP N 2 Sigambal berdasarkan wawancara yang dilakukan dengan beberapa orang guru di sekolah

\section{Panggilan Profesi}

Bakat dan panggilan batin yang kuat dalam diri mereka untuk mengajar sudah tertanam sejak lama dan berkembang setelah mereka mengikuti pendidikan keguruan. Sebagian dari mereka di mana tempat mengajar dan berapa honor yang diterima tidak begitu menjadi persoalan, yang utama adalah mereka mendapat kesempatan untuk mengajar, yaitu bertemu dengan sejumlah peserta didik dan peserta didik itu mereka ajar. Dan sebagian lagi honor merupakan bagian dari mempertahankan hidupnya dan kebutuhannya sehari-hari. Bagi guru yang menempatkan motivasi panggilan profesi untuk mengajar cenderung lebih baik dan profesional dalam menjalankan tugasnya sebagai guru, selalu berinisatif dan banyak tuntutan. Guru yang demikian ini selalu lebih mengedepankan tugas mengajarnya dibandingkan kegiatan lainnya, suka menambah ilmu dan senang berdiskusi dengan teman sejawat (guru lainnya) mengenai tugas-tugas keguruan.

\section{Pengaruh Kepemimpinan Kepala Sekolah Dalam Peningkatan Motivasi Mengajar Guru}

Kepemimpinan demokratis yang digunakan kepala sekolah cenderung menciptakan situasi yang kondusif dan membangun pola intekasi di sekolah. Berdasarkan wawancara yang penulis lakukan dengan kepala sekolah dan guru-guru berkenaan dengan kepemimpinan kepala sekolah dan motivasi mengajar guru maka dapat di pahami kepemimpinan kepala sekolah telah mampu menumbuhkan motivasi yang sesuai dan tinggi di kalangan guru, walaupun belum sepenuhnya (100\%) karena masih ada guru yang memiliki motivasi belum sesuai dengan karakternya. Karena terjadinya pengaruh yang demikian inilah dalam pelaksanaan kepemimpinan kepala sekolah SMP N 2 Sigambal telah berhasil menumbuhkan hal-hal positif dalam diri guru, antara lain :

\section{Rasa Kebersamaan}

Rasa kebersamaan yang telah dimiliki guru tumbuh karena kepala sekolah memperlakukan dan berinteraksi secara adil dan merata kepada semua guru-guru yang mengajar disekolah yang dipimpinnya, tidak subjek dan tidak pilih kasih sehingga dirasakan guru sebagai sesuatu hal yang cocok ditiru dari kepala sekolah. Baik dalam pergaulan, dalam rapat maupun dalam pembagian tugas kepala sekolah selalu berlaku objektif, adil dan menghargai guru tanpa memandang latar balakang pendidikan, statusnya. 
Hal : 47 - 52

\section{Rasa Memiliki}

Rasa memiliki di dalam hati adalah rasa yang muncul karena adanya kesadaran tentang tujuan dan arah yang akan dituju secara bersama. Kepala sekolah SMP N 2 Sigambal mendorong seluruh guru akan merasa bahwa sekolah ini adalah milik bersama yang ada didalamnya. Munculnya rasa yang demikian ini karena kepala sekolah selalu meminta pendapat dan melibatkan guru dalam setiap kebijakan yang akan diambilnya berkenaan dengan pengembangan sekolah yang dipimpinnya.

\section{Rasa Tanggung Jawab}

Maju mundurnya suatu sekolah adalah tanggung jawab bersama. Rasa tanggung jawab adalah rasa bertanggung jawab untuk kemajuan dan kemunduran sekolah dan telah dipupuk selama mengajar disekolah ini.

\section{E.Hambatan dan Penanggulangannya}

Beberapa faktor yang dirasakan sebagai penghambat yaitu:

\section{Kesadaran Guru}

Ada beberapa guru yang belum memiliki kesadaran pengabdian dalam menjalankan tugas mereka sehingga berpengaruh terhadap pelaksanaan tugas mereka sebagai guru. Biasanya guru yang demikian kurang memiliki keaktifan, kurang tanggap dan cenderung hanya bekerja untuk melaksanakan tugas semata.

\section{Terbatasnya Honor}

Keterbatasnya honor atau gaji yang diterima guru di sekolah ini terutama jika dibandingkan dengan kebutuhan hidup secara layak juga menyebabkan di antara guru kurang memiliki motivasi yang tinggi dalam melaksanakan tugasnya sebagai guru di sekolah ini. Karena besarnya kebutuhan yang menjadi alasan.

\section{Bertugas di Tempat Lain}

Banyak dari guru yang mengajar di sekolah ini juga mengajar di tempat lain, bahkan ada di antara mereka yang mengajar lebih dari dua tempat mengajar. Akibat yang nampak dikarenakan hal ini adalah terlalu sibuknya guru melaksanakan tugasnya serta terbatasnya waktu yang biasa digunakan untuk melayani murid di luar jam belajar hal tersebut karena adanya tuntutan ekonomi rumah tangga.

\section{KESIMPULAN \\ Kesimpulan}

1. Proses pelaksanaan kepemimpinan kepala SMP N 2 Sigambal diwujudkan dalam pelaksanaan kurikulum dan pengajaran, kesiswaan, personalia (guru dan tenaga administrasi), sarana dan prasarana, keuangan serta hubungan dengan orang tua murid, cenderung dilakukan kepala sekolah dengan menerapkan type kepemimpinan demokratik.

2. Meningkatakan motivasi mengajar guru yang dilakukan kepala SMP N 2 Sigambal adalah dilakukan dengan langkah-langkah meningkatkan Kesejahteraan, transparansi pengelolaan keuangan, membuka dialog, memberikan pengahargaan, melengkapi sarana dan fasilitas serta motivasi mengajat guru.

3. Pengaruh kepemimpinan kepala sekolah terhadap peningkatkatan motivasi mengajar guru dapat terjadi (walaupun belum sepenuhnya) dikarenakan tumbuh di dalam diri guru adanya rasa kebersamaan, rasa memiliki, rasa tanggung jawab serta tumbuh rasa keinginan untuk maju.

\section{UCAPAN TERIMAKASIH}

Puji dan syukur kami hadiratkan kepada Allah SWT yang telah memberikan kesehatan dan waktu kepada kami sehingga dapat menyelesaikan penelitian dan laporan penelitian ini.

Ucapan terimakasih saya ucapkan kepada kepada pihak sekolah yaitu SMP N 2 Sigambal yang telah memberikan ijin kepada saya untuk melaksanakan penelitian di sekolah tersebut.

\section{DAFTAR PUSTAKA}

Hasbullah, Dasar-Dasar Ilmu Pendidkan, Jakarta; Raja Grafindo, 2008.

Kartini Kartono, Pemimpin dan Kepemimpinan, Jakarta; Raja Grafindo, 2010.

Syafaruddin, Manajemen Mutu Terpadu dalam Pendidikan, Jakarta; Grasindo Jakarta, 2012.

Suharsini Arikunto, Organisasi dan Atministrasi, Jakarta; Raja Grafindo Persada, 2001.

Mahmud Yunus, Pokok-Pokok Pendidikan dan Pengajaran, Jakarta; Hidakarsa Agung, 2009. 
Vol. 5, No. 1, Juni 2018

$\mathrm{Hal}: 47-52$

Paulhersey and Kenned H. Blanchard, Manajemen Perilaku Organisasi Pendayagunaan Sumber Daya Manusia, Jakarta; Erlangga, 2000.

Wahjo Sumidjo, Kepemimpinan Kepala Sekolah, Jakarta; PT. Raja Grafindo Persada, Jakarta, 2009.

Djumhana, Nana, Model Pembelajaran IPA di Sekolah Menengah Pertama, Direktorat Jendral Pendidikan Islam, 2007

Gredler, Margaret, E, Learning and Intruction, Terj. Tri Wibowo, Jakarta: Kencana,2011

Hamalik, Oemar, Proses belajar mengajar, Bandung: Bumi Aksara, 2004

Harrow, Anita J, A Taxonomy of the Psychomotor Domain, New York: DAVID McKAY COMPANY, 2007

Karthwohl and Bloom, Taxonomy Of The Affective Domain, New Jersey:Educational Technology Publications, 2006

Masganti, Perkembangan Peserta Didik, Medan: Perdana Publishing, 2010

Miarso, Yusufhadi, Menyemai Benih Teknologi Pendidikan, jakarta: kencana, 2005

Moleong, Lexy. J, Metodologi Penelitian Kulitatif, Bandung: Remaja Rosdakarya, 2000

Mulyati, Psikologi Belajar, yogyakarta: andi, 2005

Nasution, S, Metode Penelitian Naturalistik Kualitatif, Bandung: Alfabeta, 2000

Slameto, Belajar Dan Faktor-Faktor Yang Mempengaruhinya, Jakarta: Rineka Cipta, 2005

Slavin, E. Robert, Psikologi Pendidikan Jilid 2, Jakarta: Indeks, 2009 